Check for updates

The BMJ

fgodlee@bmj.com Follow Fiona on Twitter @fgodlee

Cite this as: BMJ2021;372:n171 http://dx.doi.org/10.1136/bmi.n171 Published: 21 January 2021

\title{
Covid 19: Hope is being eclipsed by deep frustration
}

\section{Fiona Godlee editor in chief}

There is a palpable sense of hope in the air. ${ }^{1}$ Perhaps it's that, in the UK, the days are lengthening and spring is on its way. Or that, having reached a terrible peak, covid cases here are falling. Or that vaccines are rolling out across the world, and Joe Biden is in the White House. ${ }^{2}$

These signs of hope are real but alloyed with the hard realities of dark days ahead. Health systems and staff are under unprecedented pressure, their physical and emotional resources stretched to breaking point. Doctors and nurses are exhausted or absent because of sickness or the need to self-isolate. Many will experience moral distress or its damaging sequel, moral injury, caused by the gap between what you think should be done for a patient and what can be done under constraints beyond your control. ${ }^{3}$ In the UK it may not yet, or ever, be about whether a patient can be ventilated. But there will be times when you are unable to give patients the care they need. Covid is exacerbating the effects of chronic underfunding. Ever lengthening waiting lists mean delays that will cost lives.

When the prime minister, Boris Johnson, sought to justify a third lockdown, he cited the terrible prospect of the NHS being overwhelmed if he didn't act. He talked of a "medical and moral disaster" in which doctors and nurses could be "forced to choose which patients to treat, who would live and who would die." 4 This rhetorical flourish helped to make the decision that he didn't want to make seem inevitable and beyond his control. Now he must acknowledge that health professionals are facing these decisions every day. He must enact emergency legislation to protect doctors and nurses working in the heat of the pandemic from legal action if they act in good faith. 45

Beyond individual moral distress and injury lies the global risk of "catastrophic moral failure."6 "Vaccine nationalism" has seen rich countries buying up supplies, abandoning the world's poor and serving only to prolong the pandemic. The World Health Organization is calling for fair allocation to countries in proportion to population size. An alternative prioritisation would focus on reducing harm to health and economies. ${ }^{7}$ Worldwide shortages of vaccine are inevitable. Delaying the second dose will help. The man who led the development of the University of Oxford and AstraZeneca vaccine tells us there is direct and indirect evidence to support this approach. ${ }^{8}$

But we can't simply wait for vaccine rollout. Nor are lockdowns anything other than a pause button. Much, much more needs to be done to avoid viral transmission and mutation. ${ }^{9}$ Where is the strategy for the coming months, once lockdown lifts? ${ }^{10}$ Where are the basic public health measures to help people who want to self-isolate but can't afford to or who live in overcrowded accommodation ${ }^{11}$ Why blame and shame when what is needed is practical support? ${ }^{12}$

More palpable than hope is the deepening frustration at government inaction, missteps, and continuing incompetence.

Kar P. Partha Kar: The end of the tunnel, and the bumps on the way. BMJ 2021;372:n128. doi: 10.1136/bmj.n128 pmid: 33468553

2 Silberner J. How Joe Biden plans to heal American healthcare. BMJ 2021;372:n142. doi: 10.1136/bmj.n142 pmid: 33468497

3 Sheather J, Fidler H. Covid-19 has amplified moral distress in medicine. BMJ 2021;372:n28. doi: 10.1136/bmi.n28 pmid: 33419774

4 Dyer C. Covid-19: Doctors' call for legal protection against claims of unlawful killing is rejected. BM/2021;372:n164. doi: 10.1136/bmj.n164 pmid: 33468502

5 Dacre J. Doctors must be protected as pressure on health service grows. BMJ Opinion. 16 Jan 2021. https://blogs.bmj.com/bmj/2021/01/16/janedacre-doctors-must-be-protected-as-pressure-on-health-service-grows.

6 Covid vaccine: WHO warns of "catastrophic moral failure." BBC News. 19 Jan 2021. https://www.bbc.co.uk/news/world-55709428.

7 Herzog LM, Norheim OF, Emanuel EJ, McCoy MS. Covax must go beyond proportional allocation of covid vaccines to ensure fair and equitable access. BMJ 2021;372:m4853. doi: 10.1136/bmj.m4853 pmid: 33402340

8 Mahase E. How the Oxford-AstraZeneca covid-19 vaccine was made. BMJ 2021;372:n86. doi: 10.1136/bmj.n86 pmid: 33436419

9 Mahase E. Covid-19: What new variants are emerging and how are they being investigated?BMJ2021;372:n158. doi: 10.1136/bmi.n158 pmid: 33462092

10 Hayward A. We have entered a dangerous new phase of the pandemic. BMJ Opinion. 15 Jan 2021. https://blogs.bmi.com/bmi/2021/01/15/andrew hayward-we-have-entered-a-dangerous-new-phase-of-the-pandemic.

11 Jones B. Covid thrives on half truths and lies. BMJ Opinion. 14 Jan 2021. https://blogs.bmj.com/bmj/2021/01/14/bing-jones-covid-thrives-on-halftruth-and-lies.

12 Reicher S, Drury J. Pandemic fatigue? How adherence to covid-19 regulations has been misrepresented and why it matters. BMJ 2021;372:n137. doi: 10.1136/bmi.n137 pmid: 33461963

This article is made freely available for use in accordance with BMJ's website terms and conditions for the duration of the covid-19 pandemic or until otherwise determined by BMJ. You may use, download and print the article for any lawful, non-commercial purpose (including text and data mining) provided that all copyright notices and trade marks are retained. 